1993

\title{
Back to the Past: Why Mental Disability Law 'Reforms' Don't Reform
}

Michael L. Perlin

New York Law School, michael.perlin@nyls.edu

Follow this and additional works at: https://digitalcommons.nyls.edu/fac_articles_chapters

\section{Recommended Citation}

Perlin, Michael L., "Back to the Past: Why Mental Disability Law ‘Reforms’ Don’t Reform" (1993). Articles \& Chapters. 1205.

https://digitalcommons.nyls.edu/fac_articles_chapters/1205 


\section{Back to the Past: Why Mental Disability Law "Reforms" Don't Reform}

Michael L. Perlin*

Reviewing:

John Q. La Fond and Mary L. Durham, Back to the Asylum: The Future of Mental Health Law and Policy in the United States. New York: Oxford University Press, 1992, 266 pp.

A friend-an intelligent, empathetic, socially progressive womA an-with whom I hadn't spoken for several years called me recently. When she asked what I was doing, I told her that I was at work on a book about the insanity defense. " "The insanity defense!" she exclaimed. "Can't you do something about the way that it's always being abused?" "Abused?" I parried, "how do you mean 'abused'?" "Well," she replied, "you pick up the paper and it seems that every other defendant is pleading it, and there's always some sleazy witness who'll find some sort of syndrome and some slick lawyer who can confuse a jury. It just seems like someone's getting conned."

About six weeks before this conversation, I had received quite a different call, from the editorial desk of a major metropolitan newspaper.

Professor of Law, New York Law School, New York, New York, U.S.A.; A.B., Rutgers University 1966; J.D., Columbia University 1969.

1 Michael L. Perlin, The Jurisprudence of the Insanity Defense (forthcoming 1993). 
I was asked about a local cause célebre-an apparently randomly violent, former mental patient who was allegedly victimizing a block of a $\mathrm{New}$ York City neighborhood well known for its traditional adherence to liberal social causes. My caller told me that, in answer to his question as to why this individual was not committable in a state psychiatric hospital, he had been told by hospital staff that such commitment required proof of a "recent overt act."

I told him that that was the standard in several jurisdictions, ${ }^{2}$ but it was emphatically not a prerequisite for commitment in his state (and, in fact, that test had been specifically rejected by the state's appellate courts). ${ }^{3}$ Indeed, the New York courts had made it eminently clear that a recent overt act is not required, ${ }^{4}$ and a challenge to that standard had failed in the federal appellate courts over a decade earlier. ${ }^{5}$ My caller was quite reasonably perplexed as to why he had been given this misinformation.

I did not see the connection between the two calls until I read John La Fond and Mary Durham's masterful new work, Back to the

See, e.g., Doremus v. Farrell, 407 F. Supp. 509 (D. Neb. 1975); Lynch v. Baxley, 386 F. Supp. 378 (M.D. Ala. 1974); Lessard v. Schmidt, 349 F. Supp. 1078 (E.D. Wis. 1972)

3 See, e.g., In re Scopes, 398 N.Y.S.2d 911, 913 (1977).

4 [W] are of the opinion that such a requirement [of an overt act] is too restrictive and not necessitated by substantive due process. The lack of any evidence of a recent overt act, attempt or threat, especially in cases where the individual has been kept continuously on certain medications, does not necessarily diminish the likelihood that the individual poses a threat of substantial harm to himself or others.

Id. at 913.

On the relationship between adherence to medication regimens and involuntary civil commitment in general, see 1 Michael L. Perlin, Mental Disability Law $\$ 3.45$, at 338-41 (1989 \& Supp. 1992), and cases cited id. nn.726.1-726.3, 741 (Supp. 1992) [hereinafter Perlin, Mental Disability Law]; Michael L. Perlin, Decoding Right to Refuse Treatment Law, 16 Int'l J.L. \& Psychiatry 151 (1993) [hereinafter Perlin, Decoding].

See Project Release v. Prevost, 722 F.2d 960, 973 (2d Cir. 1983). See generally 1 Perlin, Mental Disability Law, supra note 4, 2.13, at 110-15 (discussing the role of overt acts in substantive commitment standards).
Asylum, tellingly subtitled The Future of Mental Health Law and Policy in the United States. My friend was right: someone was getting conned, although certainly not the jurors in insanity defense cases. And the editorial writer was being conned, maybe purposely, maybe inadvertently, by mental health bureaucrats desperate to avoid criticism and the harsh light of publicity. In short, the two phone calls point up the confusion, dissimulation, psychological reactance, and cognitive dissonance ${ }^{6}$ that grow in the compost heap of our mental disability law public policy. Professors La Fond and Durham's fine book is an important first step in deciphering these policies and in bringing a measure of coherence to an incoherent field.

La Fond and Durham aim to deconstruct and then reconstruct mental health law policy by looking primarily at two important areas - the substantive standards and procedural due process protections that accompany involuntary civil commitment, and the substantive tests and procedural rules that govern insanity defense trials and the postacquittal commitments of those few defendants who successfully plead insanity.

The authors' reading of these areas of the law is informed by their interpretation of the "big picture" political trends of the past quarter century: what they characterize as the liberal era (an outgrowth of the civil rights movement, the 1960 s, the Warren Court, and the emergence of public interest law as a discrete area of legal practice) and the neoconservative era (an outgrowth of public impatience with what were perceived to be the excesses of the liberal era, an increased fear of crime, the rightward turn of the Supreme Court under Chief Justices Burger and Rehnquist, and the Reagan presidency's sanctioning of greed and mean-spiritedness). ${ }^{7}$

La Fond and Durham expertly trace the complicated path of legal developments in both involuntary civil commitment and insanity

6 See generally Michael L. Perlin, Morality and Pretextuality, Psychiatry and Law: Of "Ordinary Common Sense, "Heuristic Reasoning, and Cognitive Dissonance, 19 Bull. Am. Acad. Psychiatry \& L. 131 (1991).

7 The latter characterization is mine, not the authors'. Michael L. Perlin, Competency, Deinstitutionalization, and Homelessness: A Story of Marginalization, 28 Hous. L. Rev. 63, 69 (1991). 
defense law and demonstrate how changes in these areas reflect the social and political upheavals that led to both the liberal and the neoconservative era. They state their thesis clearly in the introductory chapter:

Recent reforms holding mentally ill offenders more responsible and making involuntary hospitalization easier should not be viewed as unrelated events. They are integrally linked through the vision of the mentally ill that we share today. ... [T T he insanity defense and civil commitment reforms may be viewed as a barometer of our changing attitudes toward the disadvantaged in general and the mentally ill in particular. ${ }^{8}$

In subsequent chapters, the authors prove their case through a seamless integration of law, behavioral science, and social welfare policy.

The insanity defense, they explain, expanded during the liberal era as a reflection of an earlier outburst of optimism about the criminal justice system's potential as a rehabilitation tool, rather than simply a means of social control whose primary aim was incapacitation. The visionary view of Judge David Bazelon of the law as a tool that would "give all of us a deeper understanding of the causes of human behavior in general and criminal behavior in particular"-embodied this spirit. ${ }^{9}$

This optimism soured, however, when the public somehow conflated the expansion of the insanity defense with higher crime rates and latched on to criminal nonresponsibility defenses as a symbol exemplifying a justice system that improperly subordinated community safety concerns. As a result of this change in mood, and against the backdrop of the most sensational insanity defense trial of the twentieth century - that of John W. Hinckley, Jr.-neoconservative judges and legislators not only rolled back changes in the defense that had finally begun to take into account the teachings of twentieth-century psychology and psychiatry but also returned the defense to a more restrictive version of the M'Naghten rule, which had been seen as outdated when originally

John Q. La Fond \& Mary L. Durham, Back to the Asylum 21 (1992).

Id. at 45 (quoting David L. Bazelon, The Morality of the Criminal Law, 49 S. Cal. L. Rev. 385, 396 (1975)). adopted in England in $1843 .^{10}$ And this rollback was regarded as a tactical victory by insanity defense supporters! ${ }^{11}$

Similarly, the authors trace the history of involuntary hospitalization through several familiar landmarks: the decades of paternalism (flowing from fin-de-siècle reformers who had argued that expanded public institutions were the best cure for a variety of social ills), which peaked in the mid-1950s; the first modern reforms, stemming from a series of public and political exposés; the development of neuroleptic drugs; the implementation of welfare state-"Great Society" programs (chiefly, for these purposes, enactment of the Community Mental Health Centers Act of 1963); and the rise of the civil rights movement, through which the courts, by the early 1970s, finally concluded that the due process clause of the Constitution applied to mentally disabled persons facing involuntary civil commitment. ${ }^{12}$

By the late 1970s, though, the bloom had faded. "Deinstitutionalization" (a loaded phrase that still serves as a wonderful projective test in most cocktail party situations) became conflated with homelessness and, to a significant segment of the public, it became the perfect whipping boy for what were seen as the wretched excesses of the liberal era. ${ }^{13}$ Other major contributors to homelessness-cuts in SSI (supplemental security income), tax breaks for gentrification of decaying neighborhoods, demographic shifts-were dismissed as insignificant; deinstitutionalization, and specifically deinstitutionalization that appeared to be traceable to a minute handful of lawyers involved in a few test cases in the early seventies, became the sole villain. ${ }^{14}$

$10 \quad$ M'Naghten's Case, 8 Eng. Rep. 718 (H.L. 1843). See generally Perlin, supra note 1; 3 Perlin, Mental Disability Law, supra note 4, 15.35-15.39, at 389-402; Michael L. Perlin, Unpacking the Myths: The Symbolism Mythology of Insanity Defense Jurisprudence, 40 Case W. Res. L. Rev. 599 (1990).

113 Perlin, Mental Disability Law, supra note 4, $\$ 15.39$, at 402 (discussing Neal Milner, What's Old and New about the Insanity Plea, 67 Judicature 499, 505 (1984)).

12 See Jackson v. Indiana, 406 U.S. 715 (1972).

13 See generally Perlin, supra note 7.

14 These arguments are spelled out at greatest length, and most meretriciously, in Rael Jean Isaac \& Virginia C. Armat, Madness in the Streets: How Psychiatry and the Law 
These attitudes-abetted by a few sensational cases of former patients committing random, inexplicable crimes (generally involving victims not known to them) and coupled with the federal courts' welldocumented march to the right (especially after the entrenchment of the Rehnquist Court) - led to a new wave of "reform" legislation designed to make it easier to commit individuals who "fell through the cracks" (a favorite metaphor of neoconservative reformers). ${ }^{15}$ Such reforms, $\mathbf{L a}$ Fond and Durham contend, have proven to be counterproductive or worse; drawing on the state of Washington's experiences, they argue compellingly that such changes result in overcrowded, underfunded hospitals in which treatment is less available and in which there is no longer room for voluntary patients. ${ }^{16}$

They conclude that the situation will continue to worsen. Insanity defense "law reforms" will result in the punishment of more

Abandoned the Mentally Ill 107-60 (1990), and in a more responsible fashion in H. Richard Lamb, Deinstitutionalization and the Homeless Mentally Ill, 35 Hosp. \& Commun, Psychiatry 899, 902 (1984). For a comprehensive rebuttal of Isaac and Armat, see Keri A. Gould, "Madness in the Streets" Rides the Waves of Sanism, 9 N.Y.L. Sch. J. Hum. Rts. 567 (1992); for my response to Lamb, see Douglas Mossman \& Michael L. Perlin, Psychiatry and the Homeless Mentally Ill: A Reply to Dr. Lamb, 149 Am. J. Psychiatry 951 (1992). For a balanced and thoughtful book-length treatment of the underlying issues, see Ann Braden Johnson, Out of Bedlam: The Truth about Deinstitutionalization (1990).

This is not to suggest that many individuals did not "fall through the cracks." See, e.g., Ellen Baxter \& Kim Hopper, Shelter and Housing for the Homeless Mentally Ill, in The Homeless Mentally Ill 109, 114 (H. Richard Lamb ed., 1984) (59 percent of all patients from one New York State hospital were discharged in 1979-1980 to "unknown" living arrangements). The point is that when a crime is attributed to one of the statistically rare "false negatives" (that is, someone predicted to be not dangerous who commits a subsequent violent act), legislators often respond by enacting legislation designed to ensure that no individual in that patient's forensic category be released. Christopher Slobogin, The Guilty But Mentally Ill Verdict: An Idea Whose Time Should Not Have Come, 53 Geo. Wash. L. Rev. 494, 495 n.8 (1985) (discussing the introduction of legislation to create the guilty but mentally ill verdict in Illinois).

16 La Fond \& Durham, supra note 8, at 114-21, 167, 173. See generally Mary L. Durham \& John Q. La Fond, The Empirical Consequences and Policy Implications of Broadening the Statutory Criteria for Civil Commitment, 3 Yale L. \& Pol'y Rev. 395 (1985). seriously mentally disabled, "factually guilty" criminal defendants who may not be responsible for their acts. ${ }^{17}$ Voluntary hospitalization may become unavailable if involuntary civil commitment criteria broaden but no extra funds are spent to build new hospitals or hire new staff. Increased involuntary hospitalization (without adequate treatment) may mean that discharged patients are even less able to function in the community.

La Fond and Durham make their case well. They are persuasive and their argument is well documented. They demonstrate that the neoconservative movement has been bad for mental health care, bad for mentally disabled individuals, and bad for civil liberties-and, almost as an afterthought, it has empirically amounted to an abject failure in terms of solving the problems it laid at the feet of the liberal reformers of the sixties and seventies. They sound a measured alarm, remind us that "individual rights are ... the soul of America," and call for heightened empirical examination of the questions they raise. ${ }^{18}$

And yet, something is missing. My only real criticism of the book $^{19}$ flows from one of the authors' most telling points. Twinning the

17 On the difference between factual and moral guilt, see Louis Michael Seidman, Factual Guilt and the Burger Court: An Examination of Continuity and Change in Criminal Procedure, 80 Colum. L. Rev. 436 (1980).

18 La Fond \& Durham, supra note 8, at 168-71.

19 A minor criticism flows from some (presumably) typographical errors that might lead readers astray. For instance, the Supreme Court decided the right to training-habilitation case of Youngberg v. Romeo, 457 U.S. 307 (1982), in 1982, not in 1979. See La Fond \& Durham, supra note 8, at 126-27. Given the importance of the Supreme Court's "time line" in mental disability law (and the significance of the interplay at the Supreme Court level between Youngberg and the right to refuse treatment case of Mills v. Rogers, 457 U.S. 291 (1982)), this error may confuse readers as to the way the Court shifted its position on mental disability law issues from 1972 to 1982 . The book also inaccurately attributes the majority opinion in Youngberg to Justice Blackmun, La Fond \& Durham, supra, at 127, an opinion written by Justice Powell. Actually, Justice Blackmun, generally the Courr's conscience on matters of psychology and mental health expertise, wrote a separate concurring opinion in Youngberg criticizing the Court for not going further in providing institutionalized individuals with substantive constitutional rights. 457 U.S. 307, 325 (Blackmun, Brennan \& O'Connor, JJ., concurring). Readers familiar with Justice Blackmun's track record may be puzzled by this error. 
two areas of legal policy development reflects an important discontinuity that the authors stress:

Neoconservative insanity defense and civil commitment reforms value psychiatric expertise when it contributes to the social control functions of law and disparage it when it does not. In the criminal justice system, psychiatrists are now viewed skeptically as accomplices of defense lawyers who get criminals "off the hook" of responsibility. In the commitment system, however, they are more confidently seen as therapeutic helpers who get patients "on the hook" of treatment and control. The result will be increased institutionalization of the mentally ill and greater use of psychiatrists and other mental health professionals as powerful agents of social control. ${ }^{20}$

This insight underlies my sole frustration with Back to the Asylum-the authors' apparent belief that the presentation of rational data, well researched and amply documented, will be enough to make a difference in the direction our mental health policy takes. I wish it were so.

This is not to denigrate their contribution, but rather to suggest that this sort of research is a necessary, but not a sufficient, predicate to meaningful reconstruction of insanity defense law. I must confess to a certain amount of mea culpa here. Their approach is one that I have taken in the past; ${ }^{21}$ I now believe that considerably more is needed. Specifically, the book does not come sufficiently to grips with perhaps the essential piece of the puzzle - an explanation of why our mental health law policies remain so incoherent, why we willfully blind ourselves to empirical reality, why we obsessively focus on one piece of one explanation of a social problem and resolutely ignore all other policy choices, why we target as our bogeypersons that handful of lawyers who brought the early liberal era due process cases, and, finally and most

20

La Fond \& Durham, supra note 8 , at 156

See, e.g., Michael L. Perlin, Whose Plea Is It Anyway? Insanity Defense Myths and Realities, 79 Phila. Med. 5 (1983); Joseph H. Rodriguez et al., The Insanity Defense under Siege: Legislative Assaults and Legal Rejoinders, 14 Rutgers L.J. 397 (1983). important, why we feel the way we do about "those people" (especially those mentally disabled persons whose outward behavior parallels popular media constructs of "crazy people" and those who plead not guilty by reason of insanity to criminal charges). ${ }^{22}$ Until we address these questions, we stand no real chance of transforming our social policies.

In a series of articles, I have been grappling with this exact question. ${ }^{23}$ My tentative thesis is that our social policies in this area are shaped predominantly by what I call "sanism" - an irrational prejudice (like racism or sexism), based upon stereotype and myth, that infects both our jurisprudence and our lawyering practices. We justify sanist attitudes through our reliance on alleged "ordinary common sense" and on heuristic reasoning ${ }^{24}$ in an unconscious response to events in everyday life and in legal proceedings. ${ }^{25}$

These sanist attitudes flower perhaps most dangerously in "pretextual" judicial proceedings, in which courts accept (either implicitly or explicitly) testimonial dishonesty and engage in similarly dishonest

22

Dr. Henry Steadman and his colleagues are in the process of publishing the most comprehensive analysis of multistate insanity defense data ever assembled. Henry Steadman et al., Reforming the Insanity Defense: An Evaluation of Pre- and Post-Hinckley Reforms (forthcoming 1993). In their book, Steadman and colleagues give the lie to every one of the empirical and behavioral myths that have developed about the insanity defense, the frequency of its use, its success rate, the disposition of insanity acquittees, and the clinical conditions of such individuals. If I am wrong - and I hope I am - this research will have a transformative effect on our insanity defense policies and politics. If it does not, then I am afraid, ruefully, that reason and empiricism will not be enough.

23 See, e.g., Michael L. Perlin, On "Sanism, "46 SMU L. Rev. 373 (1992); Michael L. Perlin, Pretexts and Mental Disability Law: The Case of Competency, 47 U. Miami L. Rev. (forthcoming 1993); Michael L. Perlin \& Deborah A. Dorfman, Sanism, Social Science, and the Development of Mental Disability Law Jurisprudence, 11 Behav. Sci. \& L. 47 (1993).

24 It was this sort of heuristic reasoning that probably led my friend to recall only the vivid information that she had been reading about the insanity defense and attribute it to all other cases. See generally Donald Bersoff, Judicial Deference to Nonlegal Decisionmakers: Imposing Simplistic Solutions on Problems of Cognitive Complexity in Mental Disability Law, 46 SMU L. Rev, 329 (1992).

25 Michael L. Perlin, Psychodynamics and the Insanity Defense: "Ordinary Common Sense" and Heuristic Reasoning, 69 Neb. L. Rev. 3 (1990). 
decision making. ${ }^{26}$ Judges defend their pretextual opinions, and expert witnesses their pretextual testimony, ${ }^{27}$ through teleological reasoning based on sanist social science literature and studies, disregarding or rejecting conflicting data. ${ }^{28}$ Recognizing this bias represents a starting point for developing both a coherent jurisprudence and a coherent social policy with regard to mentally disabled persons. ${ }^{29}$ In Back to the Asylum, La Fond and Durham offer the empirical and theoretical tools to gird this undertaking.

\section{The Canadian Charter and the Protecti of International Human Rights}

\author{
Douglas Sanders
}

Reviewing:

Anne F. Bayefsky, International Human Rights $L$ Canadian Charter of Rights and Freedoms Litigatio: Butterworths, 1992, 756 pp.

William A. Schabas, International Human Rights Canadian Charter: A Manual for the Practitione. Carswell, 1991, 357 pp.

B oth of these texts deal with the role of international I law in litigation involving the Canadian Charter o. Freedoms. ${ }^{1}$ Both cover the law up to 1990 . Both incl short discussions of the topic, followed by appendices that Bayefsky's book four times as long as, and in William Sch: third again as long as, the text. This extensive use of apper the fact that international human rights law is not we Canada. Indeed, even the major international human rigl

Perlin, supra note 6, at 136-37. See generally Paul Appelbaum, The Empirical Jurisprudence of the United States Supreme Court, 13 Am. J.L. \& Med. 335, 341 (1987).

29 For the application of these principles to specific areas of mental disability law, see Perlin, supra note 1 (insanity defense); Perlin, Decoding, supra note 4 (right to refuse treatment); Michael L. Perlin, Hospitalized Patients and the Right to Sexual Interaction: Beyond the Last Frontier?, 20 N.Y.U. Rev. L. \& Soc. Change (forthcoming 1993); Michael L. Perlin, The Sanist Lives of Jurors in Death Penalty Cases: The Puzzling Role of "Mitigating" Mental Disability Evidence, Notre Dame J.L. Ethics \& Pub. Pol'y (forthcoming 1994).
Professor of Law, University of British Columbia, Vancouver, B Canada; B.A., University of Alberta 1960; LL.B., University of Alberı University of California at Berkeley 1963.

1 Can. Const. (Constitution Act, 1982) pt. I (Canadian Chart Freedoms). 